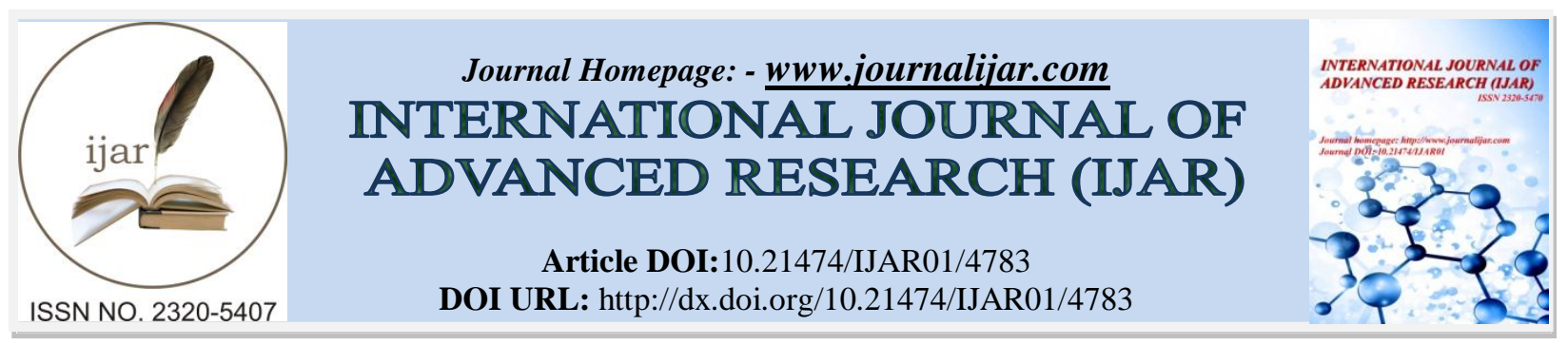

RESEARCH ARTICLE

\title{
TOWARD A RICHER DEFINITION OF MULTICULTURALISM.
}

\section{Nadia Maher Ibrahim Moawad ${ }^{1}$ and Sherine Mostafa El Shoura ${ }^{2}$.}

1. Associate Lecturer, Department of English Language and Literature, Faulty of Arts, Kafresheikh University, Egypt and a Visiting Scholar at the Department of English, College of Liberal Arts \& Sciences, University of Florida, U.S.A.

2. Associate Professor, Department of English language and Literature, Faculty of Arts, Behna University, Egypt.

\section{Manuscript Info}

Manuscript History

Received: 8 May 2017

Final Accepted: 10 June 2017

Published: July 2017

Key words:-

Multiculturalism, Cultural Diversity,

Culture, Identity, Monoculturalism,

Diversity, Immigration, Pluralism and

Integration

\section{Abstract}

The paper shows the contemporary debate surrounding multiculturalism. Actually, multiculturalism transfers from national identity to social cohesion and leads to political correctness instead of cultural friction. The paper shows a balanced assessment of the meaning of multiculturalism. It is a hotly debated and has covered a wide range of policies. For this purpose, the paper depends upon two key elements: diversity and culture.

Copy Right, IJAR, 2017,. All rights reserved.

\section{Introduction:-}

The paper presents a balanced view of most the opinions surrounding multiculturalism. Multiculturalism requires equality and its focal meaning is to include others. Its aim is the absence of bias and seeking only equal status among racial and ethnic groups. More centrally, my purpose of this article is to analyze the theory of multiculturalism and to put the best definition of it besides referring to the challenges face multicultural society. In multicultural society people enjoy equal respect, dignity, and identity due to the equal social system of their society. I am alluding to the idea of equality and belonging. Because in any organized society, belonging helps people of different ethnic background to be treated as respected, responsible, and to be protected from exclusion. Ali Rattansi (2011) defines multiculturalism as "a body of thought in political philosophy about the proper way to respond to cultural and religious diversity" (184). He provides a useful definition of multiculturalism and shows how the term is useful or misused in the political debate and public policy. I would like to ask if individuals or groups have rights under the umbrella of multiculturalism. In the light of these considerations, multiculturalism means the integration of cultural minorities into the host societies. Multiculturalism means shared values of the society as a whole and appreciation of its diversity including religious cultural, and lifestyle background. It refers to equal opportunity and antiracist society. Multiculturalism becomes an important construct for the 21th century. It allows societies and peoples to be unified through an appreciation of their cultural differences and linguistic background. The main merits of the multicultural society are equity, social justice and freedom. All the peoples all over the world seek to achieve these merits within their societies. Actually, in this paper, I aim to show how the meaning of multiculturalism is interpreted globally and how multiculturalism helps in establishing a shared world view of crosscultural knowledge.

Corresponding Author:- Nadia Maher Ibrahim Moawad.

Address:- Associate Lecturer, Department of English Language and Literature, Faulty of Arts, Kafresheikh University, Egypt and a Visiting Scholar at the Department of English, College of Liberal Arts \& Sciences, University of Florida, U.S.A. 


\section{Multiculturalism:- \\ What is Multiculturalism?}

Multiculturalism represents a major issue of political and intellectual discourse. It considered a new model for societies whose populations have become multi-ethnic through immigration. Multiculturalism is a dominating theory in Canada because Canada is characterized by immigration. Canada supports multiculturalism. Multiculturalism also encourages integration and this means that the minority groups are able to retain their home culture and ethnic community. Ali Rattans says "multiculturalism entered public discourses in the late 1960s and early 1970s, when both Australia and Canada began to declare their support for it" (9). This is a merit in a multicultural society because this requires retaining elements of ethnic community and home culture which is an important vehicle of integration. In this regard, multiculturalism means simply the acceptance of the other including his/ her ethnic beliefs and cultures and paves the way for a complete abolition of racial qualifications. In the light of these consideration, multiculturalism encompasses democratic principles such as equity, equality, freedom, social justice, and human dignity. Some scholars defined multiculturalism in terms of pluralism of racial and ethnic group (e.g., Fowers \& Richardson, 1996; Gay, 2000;Watson, 2002), others have argued that the meaning of multiculturalism is beyond pluralism and includes the desire to create new social realities from marginalized minority groups (Appiah, 1998; Gay, 1983; Glazier 1998; Goldberg, 1994; Nieto, 1999; Sleeter \& Montecinos, 1999). From this perspective (Banks, 1991; Baptise, 1980; Donaldson, 2001; Sue et al., 1999), multiculturalism promotes social justice, equal access, and opportunity for minorities and other oppressed groups. Multiculturalism is based on the idea of cultural pluralism and is based on the notion of equality among all groups and respect for cultural diversity. More generally, multiculturalism is seen as a "tenuous foundation for assorted policies based on race and ethnicity and a target of criticism for undermining the values of lockean liberalism and the norm of assimilation" (Bernstein, 1994; D'Souza, 1992; Glazer. 1975).

One of multicultural society's merits is that societies which host several nationalities and ethnicities can live together free from ethnic and religious conflict. Canada for example manages to allow people from different nationalities to live side with no religious or ethnic conflict. The best definition of multiculturalism is that:

The belief that all citizens are equal. Cultural differences make a large contribution to unity and multiculturalism celebrates that contribution. Multiculturalism also ensures that all citizens can maintain their identities, take pride in their ancestry, and have a sense of belonging. (Canadian Heritage Leaflet, 2008)

Actually, immigrants are main contributing factors to the richness of Canadian heritage and according to Pat Duffy Dutcheon "nothing prevented them from maintaining "attachments" to their culture of origin once they were fully integrated into Canadian society" (5).

\section{Culture:-}

Culture is a very close to multiculturalism hence, this paper will tackle the definition of culture? Friedrich Heckmann defines multiculturalism as an interpretation of the concept of culture as follow:

There are no "pure", original cultures. Each culture has incorporated elements of other cultures; cultures are the result of interaction with one another; culture is continuous process and change. In this sense, the cultures of immigrants are seen as opportunities for the enrichment of one's own culture. (245)

If one asks why culture is important? The answer will be because cultures operate to shape the environment, behavior, and minds of their members. Will Kymlica defines (1995) societal culture as follows:

A culture which provides its members with meaningful ways of life across a wide range of human activities, including social, educational, religious, recreational and economic life, encompassing both public and private spheres. These cultures tend to be territorially concentrated, and based on a shared language. (Multicultural Citizenship, 76)

Actually, societal cultures do not include immigrant groups as they have voluntarily left their homelands relinquishing the institutional traditions that may have secured their cultural survival. (Kymlicka, 1995). For Kymlicka, societal cultures must be granted avenues for self-government and autonomy while immigrant groups can be allotted "polyethnic rights" that will allow people to assimilate into the majority culture all the while preserving some aspects of their ancestral cultures" (Ibid, 27-33). Cultures fluctuate and change and due to modern forms of 
technology and globalization, the possibilities of preserving cultures in their ancient forms may be a lost cause. Culturalists often state that culture is a core need for individuals in order for them to build their identity, their selfesteem, and to make sense of the world around them. Multiculturalism as a basis maintains that people are shaped in some definitive way by their culture (Philip, 2007). Culture includes the symbols, images, meanings, habitual comportments, stories and so on through which people express their experience and communicate with one another (Barry 2001, 269). Mac Millian (2008) says that every person sees him/herself as an individual, but others also feel a great deal of attachment to a particular group. The group may be as small as a family unit or as big as an ethnic national group. She says that a grounded sense of belonging can allow us to feel like we are part of something higher, more essential than just ourselves; we become part of what Benedict Anderson called the "imagined community". We become part of nations, religious, or other such groups that are so large and encompassing that we can not possibly know all members, but to which we can still show a significant amount of loyalty (Ibid, 58). These feeling of belonging gives us comfort; we belong to something larger, more stable, and more enduring than ourselves. Our group predated us and will presumably survive our deaths" (Ibid, 58). Of course, when put under a microscope, it becomes immediately evident that identity is a formative process. (Ibid, 58). Benn Michaels (2006) draws attention away from cultural diversity which is aiding to ignore an ongoing and poignant reality economic inequality which perhaps is more responsible for the "barriers to ascent" than any cultural aspect (8). The devotion to diversity is in fact "at best a distraction" (Ibid, 16) and he claims that culture gives us a difference we can embrace and support rather than confront those differences that make us uncomfortable. But, he continues if we keep insisting on the notion that difference is something to be respected, we will be prevented from thinking of it as something that should be permanently eliminated. The human beings are different should be a given neither celebrated nor penalized-just a matter of fact. Benn Michaels claims that the "commitment to diversity" is trying to create a society in which, far from eliminating poverty, sees nothing objectionable about being poor, because perhaps poverty may be a part of a cultural heritage (Ibid, 109). Their difference as poor people ought to be respected. This limits the sense of responsibility of eliminating or at least drastically improving the reality of desolate poverty. Benn Michaels passionately declares that the "trouble with diversity", then, is that it cannot solve the ever-present problem of "economic inequality" and it also prevents us from seeing it as a problem at all. It makes it problematical to solve the problem of inequality but also to argue that it is indeed a problem and to offer any solutions (Ibid 72-73). Barry (2001) makes a claim that is similar to that of Benn Michaels when he says that "Multiculturalism actually directs attention away from more important problem" (321).

\section{Diversity:-}

Diversity is another issue that is related to multiculturalism. Diversity represents a great majority in the countries all over the world. Diversity has grown over the last 50 or 60 years with a general acceptance of the term "super diversity" (quoted from Marco Antonsich, 471) to reflect the impact of globalization. So, multiculturalism is a natural response to ethnic and cultural diversity. Diversity means that people of different ethnic, races, nationalities, sexes and religions background come together to form a new community. Thus, their community is a value of their community because they with different background, skills, experiences, and attitudes bring fresh ideas and perceptions to the new community. Diversity is seen as an important issue because it encourages the people to experience different things outside what they accustomed to. Also, diversity creates curiosity about learning other cultures. Therefore, cultural diversity is used with the concept of multiculturalism because multiculturalism recognizes and respects the presence of all diverse groups in a society and acknowledges their socio-cultural differences and encourages their contributions within a society. The point is that:

Multiculturalism emphasizes that acknowledging the existence of ethnic diversity and ensuring the rights of individuals to retain their culture should go hand in hand with enjoying full access to, participation in, and adhesion to constitutional principles and commonly shared values prevailing in the society.(UNESCO,1995)

Diversity is defined as the existence of "many" that are different, heterogeneous, and are not commensurable. Thus, the concept of multiculturalism endorses the idea of difference and heterogeneity that embodied in the concept of diversity. Fowers and Richardson states, "Multiculturalism stresses the importance of recognizing cultural diversity within the same political framework as well as proving equal chances and opportunities to diverse cultural groups" (Quoted from Sreelekha Mishra, 173).

One of the most important issue in this paper is the focus on the identity formations among immigrant groups. This focuses on cultural confusion and the notion of being trapped between two cultures: the culture of parents and the culture of the mainstream culture. Young people are a source of social problem by the society and the ethnic 
community. They are victimized and alienated and oppressed due to the difference between two cultures. Thus, this leads to identity crisis. In this culturalist view, an identity crisis emerges because

the young people and their parents are situated within a continuum of traditionalism, collectivism and modernity/individualism, where the dominant society stands for modern values while the minoritized group represent the pre-modern values incompatible with the modern world. (Ahmadi, 1998, Schlytter, 2004, Schlytter \&Linell, 2009, Wikan, 2002, 2003)

As a result of the growth of mixed race, mixed faith, and mixed nationalities, notions of identity also are being changed. Marco Antonsich says, "national identity and national politics are now the key determinants of our idea of difference, but national identity has never played a role in multiculturalism, other than in the sense referred to earlier, in that the majority has been expected to accommodate the minority" (474-475). Multiculturalism is about acknowledging identity in its own terms. James Clifford says:

Identity is never only about location, about shoring up a safe "home", crucial as that task may be in certain circumstances. Identity is also, inescapably, about displacement and relocation, the experience of sustaining and mediating complex affiliations, multiple attachments. (369)

Multiculturalism provides peoples with diverse perspectives including knowledge, system of oppression, and the complexities of social identities. Through multiculturalism, one seeks to escape a monoculture society by interweaving the historical perspectives of different races, classes, genders, and sexualities. Stephen Castles (2000) says that much of what is encapsulated in the term multiculturalism concerns "abandoning the myth of homogenous and monocultural nation-states" and "recognizing rights to cultural maintenance and community formation, and linking these to social equality and protection from discrimination" (5).

\section{Conclusion:-}

Finally, from my viewpoint multiculturalism is a challenge. It is a challenge to understand and accept other different cultures. It is a challenge due to misunderstanding and misconceptions among people of color and immigrants. The challenge imbedded in the real recognition of diversity and this includes both cultural diversity and community belonging. Leticia Diaz says, "Multiculturalism as a concept is both challenging and provocative. Responses to multiculturalism vary, depending on socioeconomic factors, political environments, and individual orientation to cultural pluralism" (1). So, multiculturalism is a better solution for the long history of ethnic and racial oppression all over the world. Identity and citizenship are being reconfigured by immigration and multiculturalism. Via multiculturalism, Adrian Favell (1998b) observes,

...[E]thnic minorities are offered cultural tolerance, even 'multicultural' rights and institutions, in exchange for acceptance of basic principles and the rule of law; they are imagined as culturally-laden social groups, who need to be integrated and individualized by a public sphere which offers voice and participation, transforming them from "immigrants", into full and free 'citizens'; they are to become full, assimilated nationals, in a nation- state re-imagined to balance cultural diversity, with a formal equality of status and membership. (1)

It is worth mentioning that multiculturalism is used to describe the recognition of cultural and ethnic diversity within the demographics of a particular social space. Its policies aimed at preserving different cultures or cultural identities within a unified society. Indeed, multiculturalism is a widespread concern. More specifically, multiculturalism can be seen as part of a larger "human rights revolution" in relation to ethnic and racial diversity.

\section{Works Cited:-}

1. Appiah, K. A. (1997, October 9). "The multicultural misunderstanding". The New York Review of Books, 44(15), 30-35.

2. Ahmadi, N. (1998)."Om jaguppfattningens betydelse for tolkningar av sociala normer". In N.Ahmadi. (Ed.), Ungdom, Kulturnoten, identitet.stockholm. Liber.

3. Antonsich, M. "Interculturalism versus multiculturalism- The Cantle- Modood debate". Loughborough

University, UK. Vol. 16(3) 470-493. Sagepub.co.uk/journalsPermissions.nav, 2016.

4. Banks J. A. (1991). "Teaching strategies for ethnic studies". Boston, MA: Allyn \& Bacon.

5. Barry, B. (2001). Culture and Equality. Harvard University Press. 
6. Benn Michaels, W. (2006) The Trouble with Diversity: How we learned to love identity and ignore inequality. Metropolitan Books.

7. Bernstein, R. (1994). Dictatorship of Virtue: Multiculturalism and the Battle for America's Future. New York: Alfred E. Knopf.

8. Castles, S. (2000). Ethnicity and Globalization: From Migrant Worker to Transnational Citizen, London : Sage.

9. Canadian Heritage (2008). Annual Report on the Operation of the Canadian Multiculturalism Act. Canadian Heritage, Catalogue Number CH3101/2007

10. Clifford, J. (1998) "Mixed feelings," in Cosmopolitics: Thinking and Feeling Beyond the Nation, P.Cheah and B. Robbins (eds), Minneapolis: University of MIinnesota Press, pp.362-370

11. Donaldson, K. (2001). Shattering the denial. Westport, CT: Bergin \& Garvey.

12. D'Souza, D. (1992). Illiberal Education: The Politics of Race and Sex on Campus. New York, NY: Vintage Books.

13. Duffy Dutcheon, P. (1998). Homepage:http//patduffy hutcheon.com. Retrieved May 2, 2009 at http:// patduffyhutcheon.com/papers\%20 AND \%20 Presentations/multiculturalism\% 20 in \%20 Canada.htm.

14. Diaz, L. MS. Senior Policy Advisor. "Multiculturalism". Human Rights \& International Affairs, National Association of Social Workers. Washington, D.C. U.S.A, www.socialworkers.org, May 2005.

15. Fowers, B. J., \& Richardson, F. C. (1996). "Why is multiculturalism good?" American Psychologist, 51, 609621.

16. Favell, A. (1998). 'To belong or not to belong: the postnational question,' in The Politics of Belonging: Migrants and Minorities in Contemporary Europe, A.Favell and A. Geddes (eds), Aldershot: Ashgate.

17. Gay, G. (1983). Multicultural education: Historical developments and future prospects. Phi Delta Kappan, 64, $560-563$.

18. (2000). Culturally responsive teaching: Theory, research, and practice. New York: Teachers College, Columbia University Press.

19. Glazer, N. (1975). Affirmative Discrimination: Ethnic Inequality and Public Policy. New York: Basic Books.

20. _ (1998). Is assimilation dead: Multiculturalism and American democracy. Melzer, Kansas: Kansas University Press.

21. Goldberg, D. T. (1994). "Introduction: Multicultural conditions". In D.T. Goldberg (Ed.), A Critical Reader (pp. 1-24). Cambridge, Massachusetts: Blackwell Publishers.

22. Heckmann, F. (1993). "Multiculturalism Defined Seven Days", the Social Contract.

23. Kymlica, W. (1995). Multicultural Citizenship: A Liberal Theory of Minority rights. Oxford: Oxford University Press.

24. MacMillan, M. (2008). The Uses and Abuses of History, Viking Canada (Penguin).

25. Nieto, S. (1999). Critical multicultural education and student's perspectives. In S. May (Ed.) Critical multiculturalism: rethinking multicultural and antiracist education (pp 191-215). Philadelphia, PA: Falmer Press.

26. Phillips, A. (2007). Multiculturalism without Culture. Princeton University Press.

27. Rattansi, A. (2011). Multiculturalism: A Very Short Introduction: Oxford University Press, Oxford.

28. Sleeter, C. \& Montecinos, C. (1999). "Forging partnerships for multicultural teacher education". In S. May(Ed.), Critical multiculturalism: Rethinking multicultural and antiracist education ( $\mathrm{pp}$ 113-137). Philadelphia, PA: Falmer Press.

29. Schlytter, A. (2004). Ratten Att Sjalv Fa Valja.Lund: Student Litteratur.

30. Schlytter, A. \& Linell, Hi (2009). "Girls with honour-related problems in a comparative perspective". International Journal of social welfare, 18,1-10.

31. United Nations Educational, Scientific and Cultural Organization (UNSCO). (1995). Multiculturalism; New responses to diversity. Retrieved from Http:www.unesco.org/most/pp4.htm.

32. Watson, C. W. (2002). "Multiculturalism". New Delhi: Viva Books Private Limited.

33. Wikan, U. (2002). Generous betrayal, politics of culture in New Europe. Chicago; the University of Chicago Press.

34. Wikan, U. (2003) En Fraga om heder, Stockholm: ord front forlag. 